\title{
Performance of Solar-Powered Air Conditioning System under AlMadinah AlMunawwarah Climatic Conditions
}

\author{
Khaled S. Al Qdah \\ Mechanical Engineering Department, Faculty of Engineering, Taibah University, Medina, KSA \\ Email: dr.khaled qdah@yahoo.com
}

Received 30 June 2014; accepted 21 July 2015; published 24 July 2015

Copyright (C) 2015 by author and Scientific Research Publishing Inc.

This work is licensed under the Creative Commons Attribution International License (CC BY). http://creativecommons.org/licenses/by/4.0/

(c) (i) Open Access

\begin{abstract}
Nowadays, solar-powered air conditioning has witnessed an increased progress because air conditioning system is almost a must in every building in Saudi Arabia where the outside temperature in summer is higher than $42^{\circ} \mathrm{C}$. AlMadinah AlMunawwarah is one of the important holy places in the world, and therefore, this paper investigates the design and performance of solar-powered air conditioning system integrated with photovoltaic (PV) system which consists of PV panels, solar charger, inverter and batteries. This air conditioning system can be used in non-electrified areas near AlMadinah where the cost of electricity for this area is very high. The first step in this project is the cooling load calculations for the selected space that will be cooled and it was found about 1 ton refrigeration ( $3.52 \mathrm{~kW}$ ). Based on this cooling load, the photovoltaic (PV) system has been estimated and built with the necessary connections. Data logging system has been used to measure the temperatures at the main components in the cycle like compressor inlet and outlet as well as evaporator and condenser. The input powers for the system as well as the coefficient of performance (COP) for the system under AlMadinah climatic conditions were measured along the day. The coefficient of performance varies from 2.16 to 4.22 for the system and these results compared with the conventional system performance with a good agreement.
\end{abstract}

\section{Keywords}

Performance, Solar Energy, COP, Remote Areas, Climatic Conditions

\section{Introduction}

Ten years ago energy consumption for cooling has increased dramatically in Saudi Arabia. The main reasons for 
this increasing energy demand for summer air-conditioning are the population growth, increased living standards and comfort demands as well as type of architecture; this increasing demand is one of the most significant costs to Saudi Arabia households during summer. AlMadinah AlMunawwarah one of the most holy places has a very sunny climate, with high demand for air conditioning on hot summer's days; the electricity grid increasingly faces the danger of overload due to air conditioner use, which would cause essential service disruption and severe economic impact. Solar air conditioning is one of the few solutions provided to overcome the summer high demand and addresses peak loading, and does so with reduced environmental impact at AlMadinah AlMunawwarah. Air conditioning systems in use are most often built around a vapor compression system driven by grid-electricity. In remote Saudi's villages, far from the grids, electric energy is usually supplied by diesel generators. In most of these cases, the supply with diesel fuel becomes highly expensive. Solar air conditioning might be a way to reduce the demand for electricity. Therefore, this work focuses in the design and construction of solar-powered air conditioning system integrated with photovoltaic (PV) system. According to the solar radiation map shown in Figure 1 [1], it can be seen that solar energy is the best source to generate electricity in Saudi Arabia and specifically AlMadinah city where the annual intensity of solar radiation varies from 2200 to $2400 \mathrm{kWh} / \mathrm{m}^{2}$, making it potential to consider the solar energy as the best option for power generation.

A lot of research is conducted for this purpose especially in countries where there is high availability of solar energy just like Saudi Arabia and the most previous works that conducted solar cooling and solar air conditioning are as follows.

Sayigh (1981) [2] performed that comparisons for a hot, arid climate like that of Riyadh, Saudi Arabia are made for four solar air conditioning systems. Mattarolo (1982) [3] conducted a general survey of solar-powered air conditioning systems, including descriptions of a continuous open cycle absorption cooler, and dehumidification-humidification systems. Solar-powered air conditioning system was designed, installed and operated in Singapore (Bong, 1987 [4]). Aly and Fathalah (1988) [5] presented a combined absorption-desiccant high performance air conditioning system suitable for hot humid areas. Feasibility of utilizing solar power for comfort cooling in Hong Kong has been studied; a solar-powered absorption air conditioning system was designed and successfully constructed on the campus of the University of Hong Kong (Yeung, 1992 [6]). Tsilingiris (1993) [7]

\section{Global Horizontal Irradiation}

Saudi Arabia

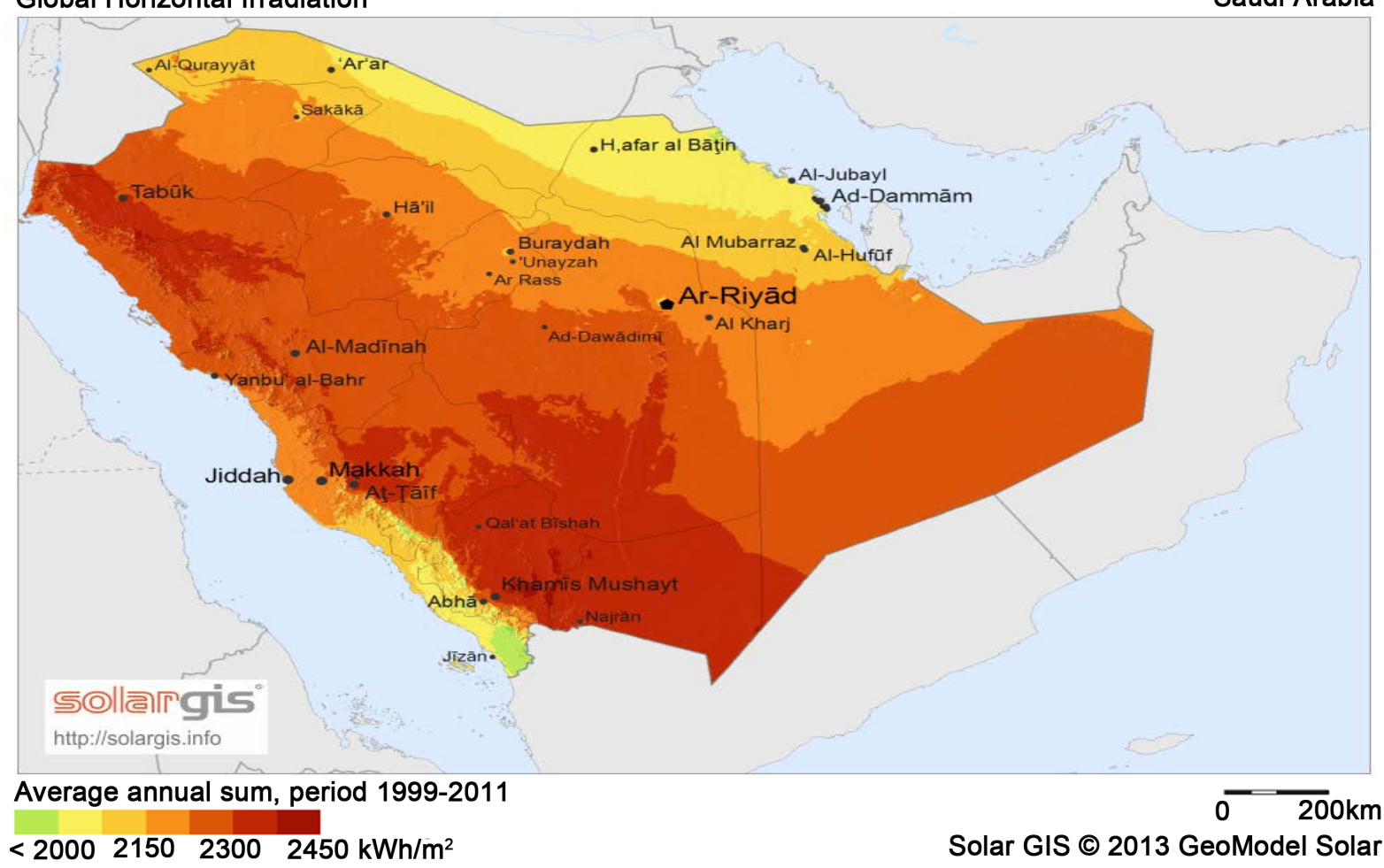

Figure 1. Annual solar radiation map for Saudi Arabia. 
conducted the development of a theoretical microcomputer model suitable for performance predictions and investigation of the operational behavior of a simple solar cooling system for small residential applications. A hybrid open-cycle vapor absorption and liquid desiccant system using $\mathrm{LiBr}$ for the process of absorption and dehumidification has been simulated and the COP so obtained is about $50 \%$ higher than that of conventional vapor absorption (Khalid Ahmed et al., 1997 [8]). Li and Sumathy (2000) [9] reviewed solar-powered air conditioning systems with the absorption air of lithium bromide and water. A number of attempts have been made by researchers to improve the performance of the solar applied air conditioning (chiller) subsystems. The feasibility of solar-powered absorption cooling technology under Tunisian conditions has been carried out (Moncef Balghouthi, 2005 [10]). Mittal et al. (2005) [11] presented a work that will help many researchers work in the area of air conditioning and provide them with fundamental knowledge on absorption systems. Sayigh (2007) [12] conducted the theoretical behavior of thermal parameters and their interaction in absorption cooling systems powered with solar energy. Constantinos et al. (2007) [13] described the main results of the EU project SACE (Solar Air Conditioning in Europe), aimed to assess the state-of-the-art, future needs and overall prospects of solar cooling in Europe. Solar-powered adsorption air conditioning system was designed and installed in the green building of Shanghai Research Institute of Building Science (Zhai et al., 2008 [14]). Umberto et al. (2009) [15] analyzed the technical and economic feasibility of solar absorption cooling systems, designed for two different application fields: industrial refrigeration and air conditioning. Paula Naukkarinen (2009) [16] discussed the solar air conditioning and its role in alleviating the energy crisis of the Mediterranean hotels. Koroneos.et al. (2010) [17] investigated the use of thermal solar system in the medical centre applications. A solar hybrid desiccant air conditioning system has been configured, experimentally investigated and theoretically analyzed (Dong La et al., 2011 [18]). The potential applications and advantages of powering solar air-conditioning systems using concentrator augmented solar collector (Dan et al., 2012 [19]). Lavinia and Mario (2012) [20] investigated the solar heating and air-conditioning by GSHP coupled to PV system for a cost-effective high-energy performance building.

It can be seen that many researchers conducted solar cooling and solar-powered air conditioning systems but none of these conducted the potential of solar power air conditioner in Saudi Arabia especially AlMadinah region in spite of its climatic conditions, which is the motivation of this work. This project will focus on the design and construction of solar-powered air conditioning system integrated with photovoltaic (PV) system which is easy to use in AlMadinah AlMunawwarah and the non-electrified remote areas outside AlMadinah where the intensity of solar radiation reaches to $7.5 \mathrm{kWh} / \mathrm{m}^{2}$ a day.

In this work, the design of the solar-powered air conditioning system is described in detail and its performance over an entire cooling season will be investigated by utilizing the PV panels to generate necessary power for small-scale air conditioning system about 1 TR and compare the system performance with the conventional system.

\section{Method and Materials}

Many tools are available for sizing the PV system with battery storage. The steps below summarize the methodology for this investigation.

\subsection{Collection of the Required Meteorological Data}

Such as design temperatures, humidity, tilt angle, daily and annual values of solar radiation for the site and the number of working hours. The space that has been chosen to be cooled in this work is the office room with $4 \times 4$ $\times 3 \mathrm{~m}$ used by faculty member located inside AlMadinah and the first step to size the air conditioner is the cooling load estimation for this selected space.

\subsection{Cooling Load Calculations}

Cooling load includes what kind of cooling and how much of cooling needed. The space that will be cooled in this work for eight working hours a day located near AlMadinah city. Hourly analysis program (HAP) used, this program calculating the cooling load for any location. First of all the site must be specified as well design inside and outside design temperature and relative humidity, thickness and type of insulation materials used and the building structure. The design temperature used are $45^{\circ} \mathrm{C}$ as a maximum temperature during summer and the comfort temperature or the inside temperature is $23^{\circ} \mathrm{C}$ and the relative humidity of $50 \%$ [21]. Finally the output of the program will be displayed for each month. Figure 2 displays the maximum and minimum cooling load for 


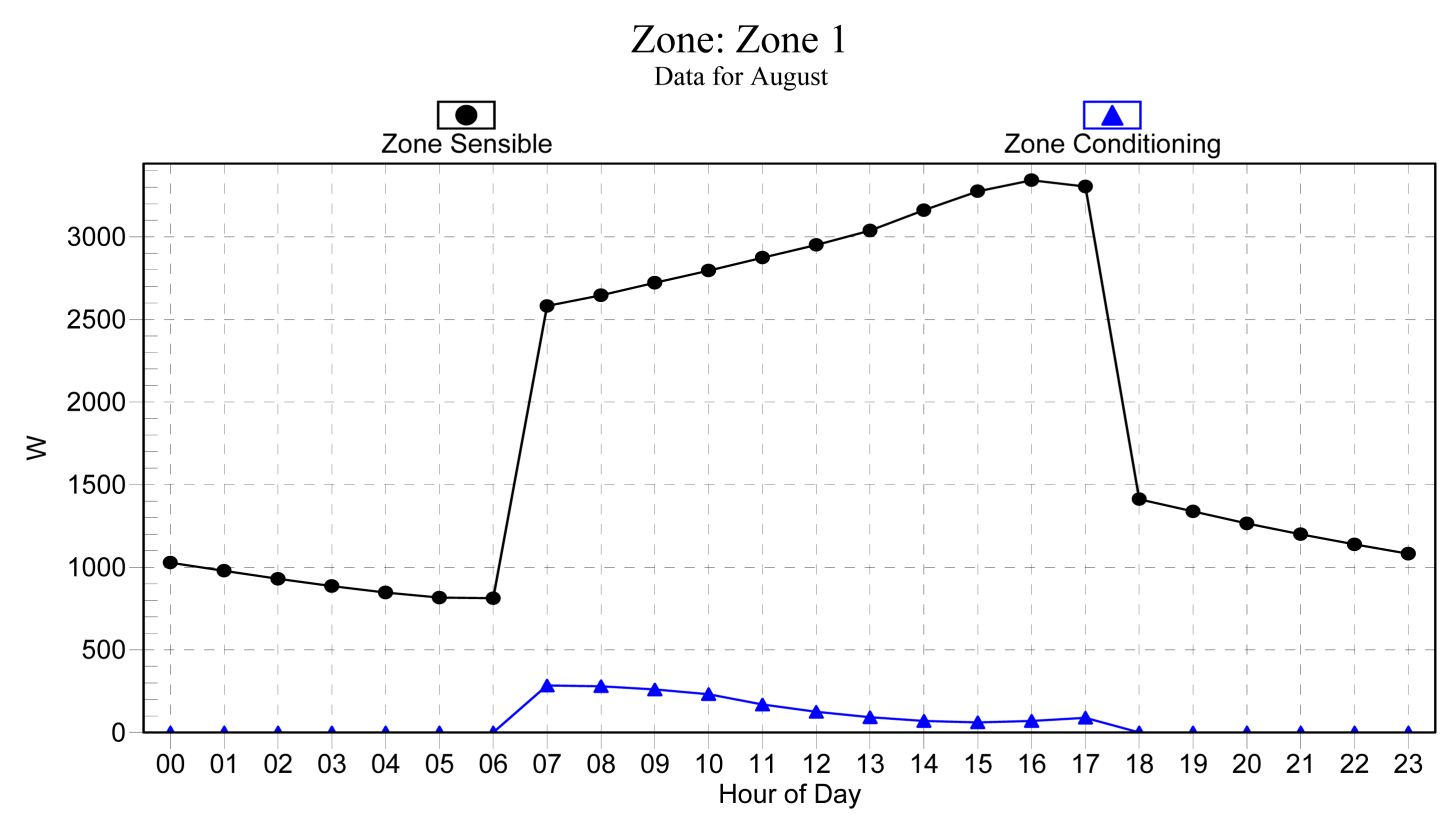

Figure 2. Maximum cooling load during August.

this space. It was found that the maximum cooling load during August it is about $3.4 \mathrm{~kW}$ where as the minimum cooling load during January $2.4 \mathrm{~kW}$.

\subsection{Design and Sizing of the Air Conditioning System}

Based on cooling load calculations, the air conditioning unit has been selected with the following specification: unit capacity $3.52 \mathrm{~kW}$ or 1 ton refrigeration (1 TR) split unit, $220 \mathrm{~V}$, input power $1.250-1.374 \mathrm{~kW}$ to provide the suitable COP.

\subsection{PV System Sizing and Material Selection}

Based on air conditioning unit capacity that has been selected under AlMadinah climatic conditions and the data collected, where the intensity of solar radiation about $7.5 \mathrm{kWh} / \mathrm{m}^{2}$, the PV solar-powered system specifications can be selected and design.

A photovoltaic system is an array of components designed to supply usable electric power for a variety of purposes [22]. The sun delvers its energy to us in two main forms, heat and light. There are two main types of solar power systems, namely, solar thermal systems that convert heat to electricity, and solar PV systems that convert sunlight directly into usable direct current (DC) electricity. One or more DC to alternating current (AC) power converters which called inverters. PV cells are made from layers of semi-conducting material, usually silicon. When light shines on the cell it creates an electric field across the layers. The stronger the sunshine, the more electricity is produced. Groups of cells are mounted together in panels or modules that can be mounted on your roof [22]. The peak sun hour is essential in order to know the number of PV modules to be installed. Before doing so, the power that can be assumed generated by the PV modules must be determined based on solar irradiance of the location.

The function of charger is to regulate the voltage and current coming from the solar panel going to the battery. The battery is the key components in PV-SA systems as it act as energy back-up for the renewable energy systems. It also functions as storage devices for storing PV generated electricity during cloudy days and at night. In order to apply this system in AC load, the inverter is needed to convert the DC electricity generated by the PV panel into AC. The AC load is a common type of load and easily available with cheaper in price.

As we mentioned previously, the purpose of charge controller is to regulate the current from the PV module to prevent the batteries from overcharging. A charge controller is used to sense when the batteries are fully charged and to stop, or decrease, the amount of current flowing to the battery [23]. The solar energy is received by the PV module and transform into electrical energy. The electrical energy is then being regulated by charge control- 
ler either by supplies it directly into the load or charges the batteries. As the electrical energy coming from the PV module is in DC, inverter will convert it into AC as the compressor needs AC to operate. The electricity provided by the panel array and battery is $\mathrm{DC}$ at a fixed voltage. The voltage provided might not match what is required by the load. A direct/alternating (DC/AC) converter, known as inverter, converts the DC current from batteries into AC.

The charge controller specification are, $12 \mathrm{~V}$, rate charging control 24 Amp.

A voltage regulator is designed to automatically maintain a constant voltage level

$$
\begin{gathered}
\mathrm{COP}_{\text {cooling }}=\frac{\text { Desiredoutput }}{\text { InputPower }} \text { [24] } \\
W=\frac{3520 \mathrm{~W}}{2.52}=1397 \mathrm{~W}
\end{gathered}
$$

where the acceptable COP for the system recommended by the supplier should be 2.52 .

Input power range: 1250 to $1397 \mathrm{~W}$.

We need $1397 \mathrm{~W}$ with 8 working hour per day

work $\times$ working hours in day $=$ work hours perday

$$
13978 \times 8=11176 \mathrm{~W} \cdot \mathrm{hr} / \text { day }
$$

Minimum hour for sunlight per day $=6 \mathrm{hr} /$ day

$$
\begin{gathered}
\text { Total load capacity }=\frac{\text { work per day }}{\text { minimum hour for sunlight per day }} \\
\text { Total load capacity }=\frac{11176 \mathrm{~W} \cdot \mathrm{hr} / \text { day }}{6 \mathrm{hr} / \text { day }}=1863 \mathrm{~W}[24]
\end{gathered}
$$

We need photovoltaic solar system with capacity $1863 \mathrm{~W}$.

The available size of panel with the standard $310 \mathrm{~W}$ output.

$$
\text { Number of panels }=\frac{\text { Total Capacity }}{\text { The output for } 1 \text { panel }}=\frac{1863 \mathrm{~W}}{310 \mathrm{~W}}=6 \text { Panels }
$$

therefore we need 6 panel at $310 \mathrm{~W}$ each. Assuming drop voltage 30\% [23]

$$
150 \times 30 \%=45 \mathrm{~A} \cdot \mathrm{h}
$$

The minimum efficiency of battery $90 \%$.

The actual amperes of battery is $(90 \% \times 150)-45=90 \mathrm{~A} \cdot \mathrm{h}$.

The actual capacity of one battery: $90 \mathrm{~A} \cdot \mathrm{h}$, working hours: $8 \mathrm{~h}$.

The actual Amp. $\frac{90 \mathrm{~A} \cdot \mathrm{h}}{8 \mathrm{~h}}=11.25 \mathrm{~A}$.

The running current of air conditioning unit is $5.68 \mathrm{~A}-7.6 \mathrm{~A}$ with starting current of $22.8 \mathrm{Amp}$.

Number of battery $\frac{22.8 \mathrm{~A}}{11.25 \mathrm{~A}}=2$ batterys : for 8 hour.

Number of battery's for two days $2 \times \frac{48 \mathrm{~h}}{8 \mathrm{~h}}=12$ batteries.

With total power stored $1863 \mathrm{~W}, 12$ Volt and 150 Ah.

The inverter specification are: DC input $48 \mathrm{~V}$, AC output $220-240 \mathrm{~V}$, output power $5 \mathrm{~kW}$ and the charge controller 12 Volts each and charge rating 24 Ampers with over load and short circuit protection.

\subsection{PV Installation and Tilt Angle Selection}

In order to make the system work efficiently, the inclination angle for the panels (Tilt angle) should be carefully selected. The optimum tilt varied from month to another and the collected solar energy depends on the optimum 
panel tilt for each month. It was found that the average optimum tilt angle at Madinah for the winter months is $37^{\circ}$ and for the summer months is $12^{\circ}$. So, the yearly average tilt panel is $23.5^{\circ}$ which nearly corresponding to the latitude of Madinah site $24.5^{\circ}$ [24].

\subsection{PV System Installation and Connections}

After the material selection for PV panels, batteries, charge controller and inverter then using suitable basement, cabinets to protect the system, the frame for the panels designed at an optimum tilt angle, the system installed with the help of technical as shown in Figure 3 which explain the actual final cycle that includes the air conditioning unit and power supply system that can be used at any time; the system has been tested for 8 hours per day with a full capacity.

\section{Results and Discussion}

The most common type of air conditioning is technically referred to the vapor-compression refrigeration system. The operation of the air conditioning system starts when the refrigerant flows across the evaporator inside the space to absorb heat. The refrigerant that went into the evaporator leaves as vapor. Then, the low pressure and cool vapor is taken outside and compressed by the compressor to become a hot, high pressure gas. Compressor is electrically operated can be described as the heart of air conditioning system as it pump refrigerant throughout the system. The main function of a compressor is to compress refrigerant vapor to a high pressure, making it hot for the circulation process. Next, the hot vapor pass through the condenser and gives off some of its heat as outdoor air is blown across the condenser coil. The warm liquid is carried back to the evaporator to repeat the cycle again.

The system performance measured by measuring the temperature at each previous component in the cycle by using data logging system connected with thermocouples, these data transfer through the USB to the computer for analysis where a lot of readings carried out through a specific time. The system worked between 9 am to 17 pm usually for 8 hours a day, Extensive measurement were taken through the two months ago.

To find the coefficient of performance which represents the system efficiency, the main properties for the working fluid which are; temperature, pressure, enthalpy and entropy must be reported, the refrigerant or the working fluid in this cycle is R22. Suction and discharge pressure for the system measured as well as mass flow rate in the cycle. Figure 4 represents the refrigeration cycle on the temperature-entropy (T-S) diagram [25].

From this figure the points from 1 - 4 can be described as follow:

Point4: $T_{4}$ : Temperature at the inlet of the compressor where the liquid enters as dry saturated vapor.

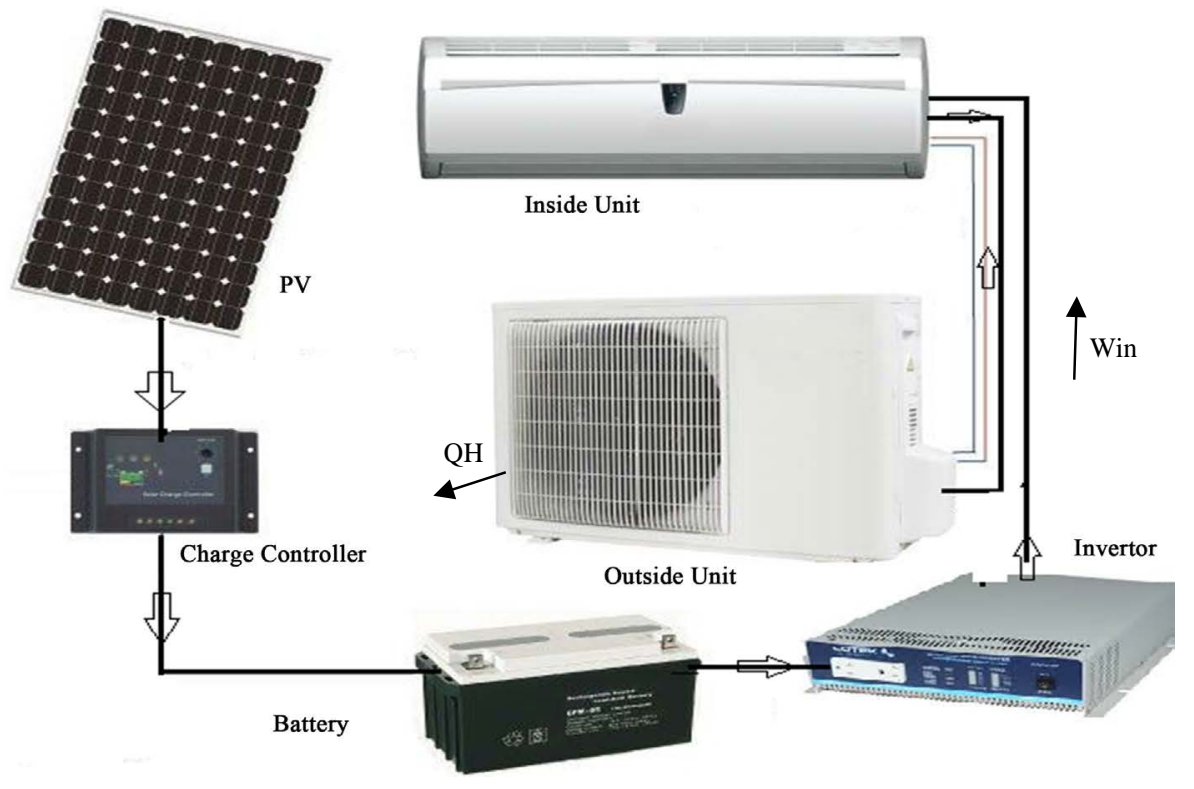

Figure 3. Final actual system cycle. 


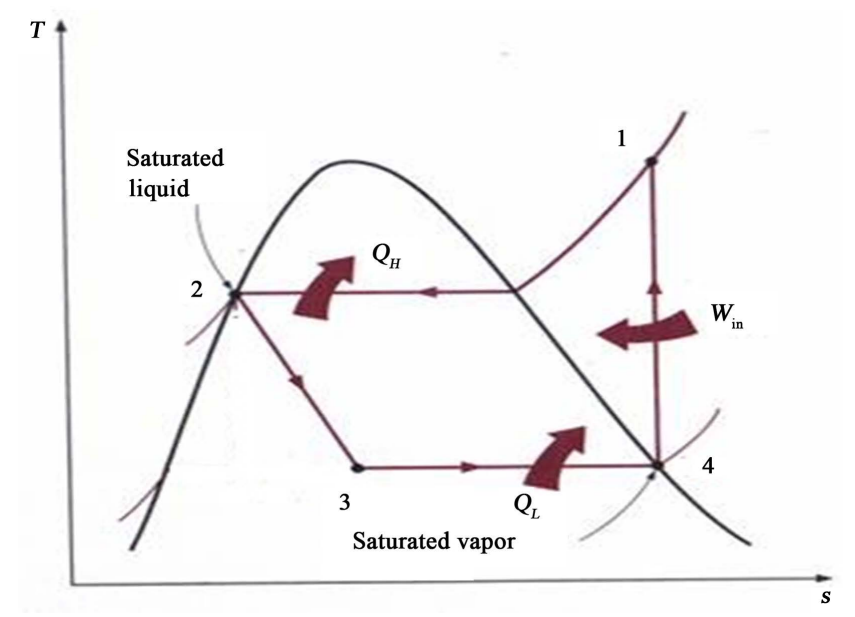

Figure 4. Refrigeration cycle.

$T_{1}$ : Temperature at compressor outlet where the refrigerant leaves the compressor as superheated vapor.

$T_{2}$ : Temperature of condenser where the refrigerant leaves as saturated liquid.

$T_{3}$ : Temperature of evaporator where evaporation takes place at constant temperature.

The quality $x$ for point 4 is one and for point 2 is zero

$$
x_{4}=1 \text { and } x_{2}=0 \quad \dot{m} \approx 0.03 \mathrm{Kg} / \mathrm{s}
$$

$h_{2}=h_{3}$ where $h$ is the enthalpy $(\mathrm{kJ} / \mathrm{kg})$ and the pressure $P_{2}=P_{1}$.

From the tables of refrigerant (R22) properties available online [26], the enthalpy can be found directly at specified temperature and pressure. The cooling load or refrigeration capacity $Q L=\dot{m}\left(h_{4}-h_{3}\right)$.

The input power or work input is $W$ or $h_{1}-h_{4}$ and the direction shown in Figure 5.

$$
\mathrm{COP}=\frac{h_{4}-h_{3}}{h_{1}-h_{4}}[24], \mathrm{COP}=\frac{\dot{m}\left(h_{4}-h_{3}\right)}{p}[24]
$$

Figure 5 represents the variation of COP with time during last May, it can be seen that the higher value of COP measured in the morning where the outside temperature still low and the system is fully charged. The same trend can be seen in Figure 6 for the system performance through June where the summer takes place and the outside temperatures higher than $40^{\circ} \mathrm{C}$. The COP is a function of compressor input work and the desired output, the higher values indicated that the cooling capacity is at its optimum values during the first hours then the compressor needs more work which means lower COP. From these figures the COP can be considered with its normal ranges for these types of air conditioning system powered by conventional power systems but the PV system is clean, safe and reliable system in spite of the high cost.

During the last two months, the system performance examined under variable intervals of time and the temperatures at each point in the cycle were measured by the thermo couples KT-type connected to Omega data logging system. Figure 7 display the variation of temperature for each component during last may in the morning where the temperature outside temperature in this day reaches $39^{\circ} \mathrm{C}$. The compressor outlet temperature which is the highest temperature in the cycle varied between $40^{\circ} \mathrm{C}$ to $64^{\circ} \mathrm{C}$ at constant value of condenser temperature $23^{\circ} \mathrm{C}$. Generally, the inlet of the compressor and exit of evaporator temperature usually closed to each other which mean normal operation to the air conditioning system.

Figure 8 shows the variation of temperatures with time in the afternoon from $1 \mathrm{pm}$ to $5 \mathrm{pm}$ at the beginning of June where the outside temperature $42^{\circ} \mathrm{C}$, the compressor usually switch off by the control system when in the temperature of the space $23^{\circ} \mathrm{C}$, small deviation between the inlet of compressor and evaporator temperature during this test which is due to outside temperature variation and the continuous door opening for the room from the occupants.

Figure 9 display the variation of temperature during June from 12 to 3:00 pm, Normal operation for the system but the system COP seemed to be lower than that for the optimum value because during that day the 


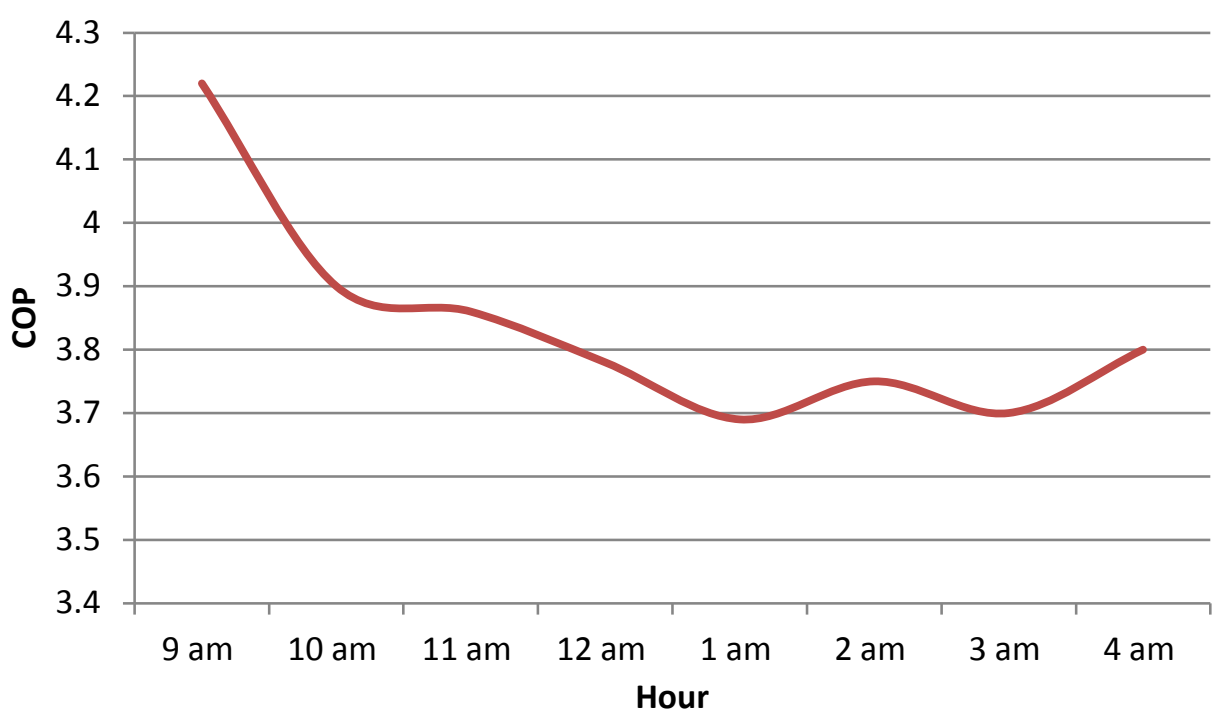

Figure 5. Coefficient of performance during May.

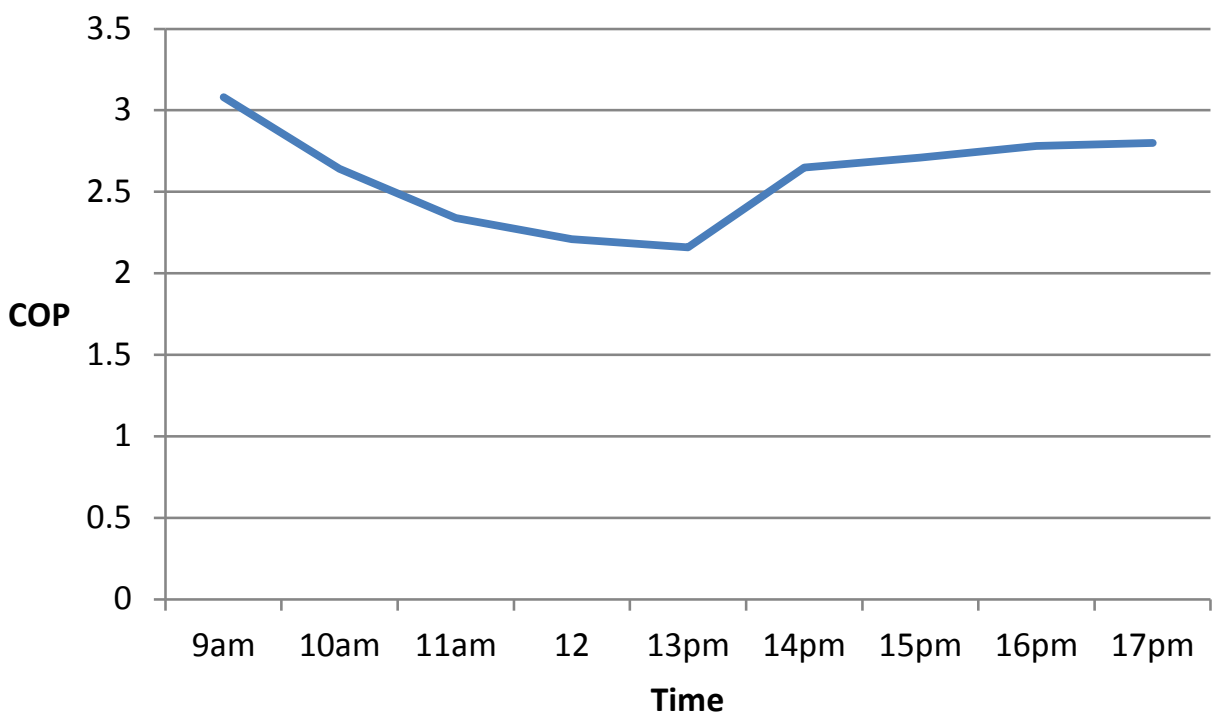

Figure 6. Coefficient of performance during June.

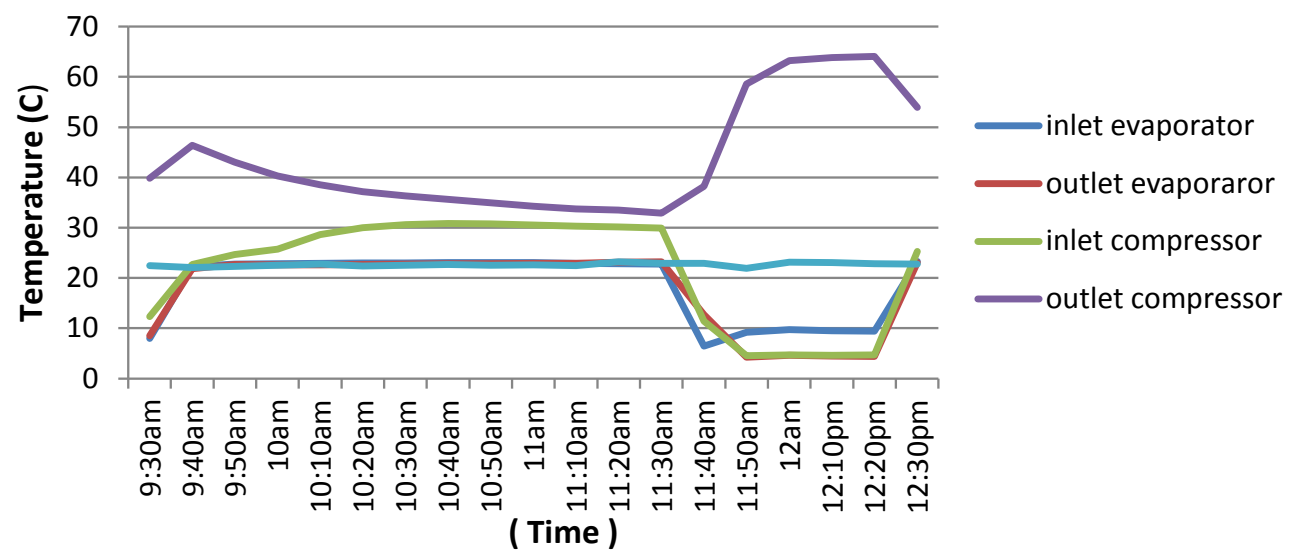

Figure 7. Variation of cycle temperature from 9:30 am to 12:30 pm during May. 


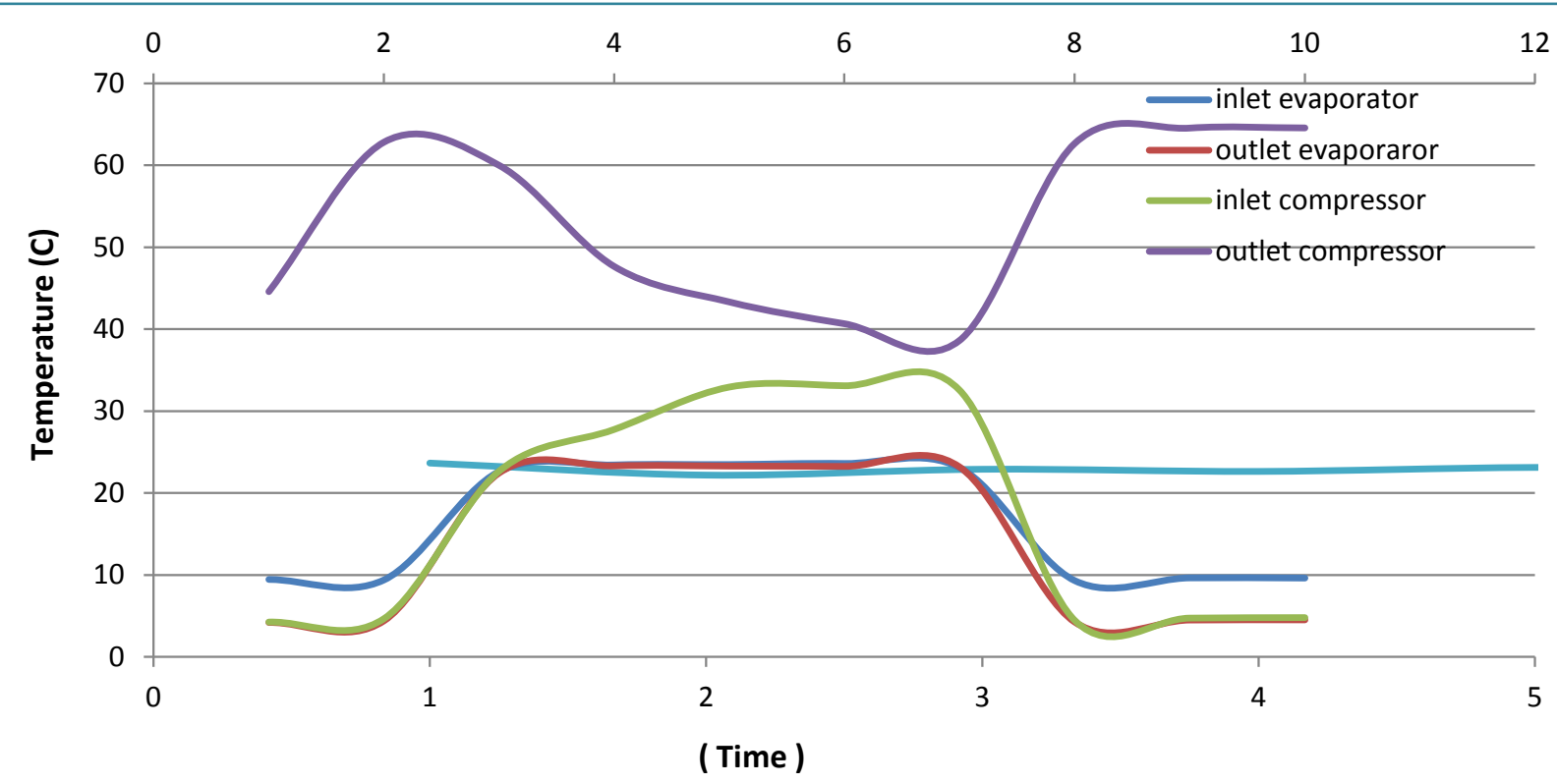

Figure 8. Temperatutre variations from 1:00 pm to 5:00 pm.

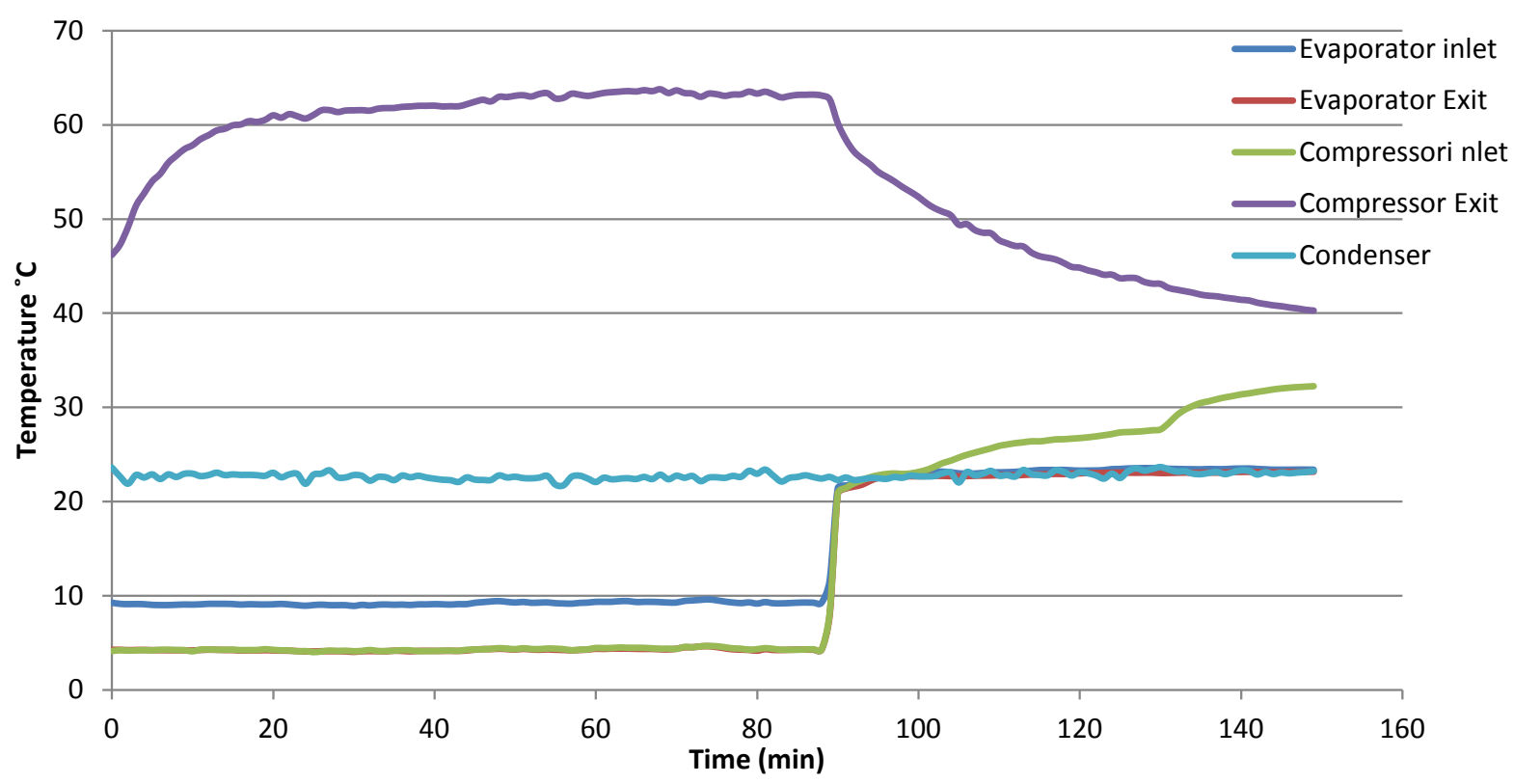

Figure 9. Temperature variations from 12:30 pm to 3:00 pm.

weather was stormy and the dust cover the $\mathrm{pV}$ panels and the input power affected by this action. It is necessary to clean and wash the PV panels if we want to get a higher output from these pannels. From the results obtained using solar energy as a power source it can be said that solar air-conditioning might be a way to reduce the demand for electricity. Therefore, this work focuses in the design and construction of solar-powered air conditioning system integrated with photovoltaic (PV) system.

Solar air conditioning at an economically competitive level could reduce electricity costs for residential and small buildings and this would cut the growth of peak electric demand.

About $70 \%$ of the power used in Saudi Arabia in the summertime goes into air conditioning (according to Saudi Electricity Company). The approximate cost for the system including installation about 46,000 SR and this cost can be considered high when we compare it with electricity price in Saudi Arabia. Recent price drops of PV panels however have changed this system can be utilized efficiently in remote areas where the electricity 
generation becomes more cost. In spite of the cost, solar energy as a power source to the air conditioning system is one of the few solutions that provides to overcome the summer high demand and addresses peak loading. On hot summer's days, the electricity grid increasingly faces the danger of overload due to air conditioner use in addition to its advantages as a clean and safe energy. The air conditioning system can be operated on solar and can be used in non-electrified areas. As we all known, solar energy is cost effective, renewable and environmentally friendly.

\section{Conclusions}

This work focuses on design, construction and testing the performance of solar-powered air conditioning system integrated with photovoltaic (PV) system and applying it under AlMadinah AlMunawwarah climatic conditions. The project comes as a solution to reduce the electric demand especially during the summer and can be used efficiently in remote area where the electricity is not available. It was designed by two different methods: one of them is preferred upon the other because of the acceptable range of the voltage and the easy connection. The COP for the system is found to be with a good agreement with conventional system

Also, it is extremely difficult to keep the performance of the system components to be constant over entire experimental period as the components deteriorate with time.

As the rate of air-conditioned demand is expected to grow, the exploitation of solar energy, especially in Gulf countries, like Saudi Arabia, during the hot season, seems to be a valuable option to mitigate the consumption of conventional fuels due to the cooling requirements. Solar air conditioning systems can be a reasonable alternative to conventional air conditioning systems. There are several characteristics that must be considered to know either on the PV system or on the air conditioning system such as electrical equivalent, characteristic curve, and factors affect the output of PV cells.

Solar energy as a power source can reduce peak energy demand and increase the use of renewable energy, while providing energy savings to the end user.

\section{Acknowledgements}

The author would like to express deep thanks and gratitude to the Deanship of Scientific Research at Taibah University for the technical and financial supports and encouragement.

\section{References}

[1] http://solargis.info/doc/free-solar-radiation-maps-GHI

[2] Sayigh, A.A.M. (1981) Solar Air Conditioning in a Hot Arid Climate. Proceedings of the Second Miami International Conference, Miami Beach, 10-13 December 1979, 761-773.

[3] Mattarolo, L. (1982) Solar Powered Air Conditioning Systems: A General Survey. International Journal of Refrigeration, 5, 371-379. http://dx.doi.org/10.1016/0140-7007(82)90059-7

[4] Bong, T.Y, Ng, K.C. and Tay, A.O. (1987) Performance Study of a Solar-Powered Air-Conditioning System. Solar Energy, 39, 173-182. http://dx.doi.org/10.1016/S0038-092X(87)80025-7

[5] Aly, S.E. and Fathalah, K.A. (1988) Combined Absorption-Desiccant Solar Powered Air Conditioning System. Wärmeund Stoffübertragung, 23, 111-121. http://dx.doi.org/10.1007/BF01637133

[6] Yeung, M.R., Yuen, P.K., Dunn, A. and Cornish, L.S. (1992) Performance of a Solar-Powered Air Conditioning System in Hong Kong. Solar Energy, 48, 309-319. http://dx.doi.org/10.1016/0038-092X(92)90059-J

[7] Tsilingiris, P.T. (1993) Theoretical Modelling of a Solar Air Conditioning System for Domestic Applications. Energy Conversion and Management, 34, 523-531. http://dx.doi.org/10.1016/0196-8904(93)90143-X

[8] Khalid Ahmed, C.S., Gandhidasan, P. and Al-Farayedhi, A.A. (1997) Simulation of a Hybrid Liquid Desiccant Based Air-Conditioning System. Applied Thermal Engineering, 17, 125-134. http://dx.doi.org/10.1016/S1359-4311(96)00025-7

[9] Li, Z.F. and Sumathy, K. (2000) Technology Development in the Solar Absorption Air-Conditioning Systems. Renewable and Sustainable Energy Reviews, 4, 267-293. http://dx.doi.org/10.1016/S1364-0321(99)00016-7

[10] Moncef, B., Chahbani, M.H. and Amenallah, G. (2005) Solar Powered Air Conditioning as a Solution to Reduce Environmental Pollution in Tunisia. Desalination, 185, 105-110. http://dx.doi.org/10.1016/j.desal.2005.03.073

[11] Mittal, V., Kasana, K.S. and Thakur, N.S. (2005) The Study of Solar Absorption Air-Conditioning Systems. Journal of 
Energy in Southern Africa, 16, 59-66.

[12] Sayegh, M.A. (2007) The Solar Contribution to Air Conditioning Systems for Residential Buildings. Desalination, 209, 171-176. http://dx.doi.org/10.1016/j.desal.2007.04.038

[13] Constantinos, A., Gershon, G., Hans-Martin, H., Carlos, A., Infante, F., Erich, P., Wang, L. and Edo, W. (2007) Solar Air Conditioning in Europe-An Overview. Renewable and Sustainable Energy Reviews, 11, 299-314. http://dx.doi.org/10.1016/j.rser.2005.02.003

[14] Zhai, X.Q., Wang, R.Z., Wu, J.Y., Dai, Y.J. and Ma, Q. (2008) Design and Performance of a Solar-Powered Air-Conditioning System in a Green Building. Applied Energy, 85, 297-311. http://dx.doi.org/10.1016/j.apenergy.2007.07.016

[15] Umberto, D., Stefania, P. and Paolo, S. (2009) Solar-Powered Cooling Systems: Technical and Economic Analysis on Industrial Refrigeration and Air-Conditioning Applications. Applied Energy, 86, 1376-1386. http://dx.doi.org/10.1016/j.apenergy.2009.01.011

[16] Naukkarinen, P. (2009) Solar Air Conditioning and Its Role in Alleviating the Energy Crisis of the Mediterranean Hotels. International Journal of Sustainable Energy, 28, 93-100.

[17] Koroneos, C., Nanaki, E. and Xydis, G. (2015) Solar Air Conditioning Systems and Their Applicability: An Exergy Approach. Resources, Conservation and Recycling, 55, 74-82. http://dx.doi.org/10.1016/j.resconrec.2010.07.005

[18] La, D., Dai, Y.J., Li, Y., Ge, T.S. and Wang, R.Z. (2011) Case Study and Theoretical Analysis of a Solar Driven Two-Stage Rotary Desiccant Cooling System Assisted by Vapor Compression Air-Conditioning. Solar Energy, 85, 2997-3009. http://dx.doi.org/10.1016/j.solener.2011.08.039

[19] Nkwetta, D.N. and Smyth, M. (2012) The Potential Applications and Advantages of Powering Solar Air-Conditioning Systems Using Concentrator Augmented Solar Collectors. Applied Energy, 89, 380-386. http://dx.doi.org/10.1016/j.apenergy.2011.07.050

[20] Lavinia, C.T., Mario, M. and Claudio, D.P. (2012) Solar Heating and Air-Conditioning by GSHP Coupled to PV System for a Cost Effective High Energy Performance Building. Energy Procedia, 30, 683-692. http://dx.doi.org/10.1016/j.egypro.2012.11.078

[21] McDowall, R. (2007) Fundamentals of HVAC Systems. American Society of Heating, Refrigerating and Air-Conditioning Engineers, Inc. and Elsevier Inc., Atlanta.

[22] Saad, S.S., Daut, I., Misrun, M.I., Champakeow, S. and Ahmad, N.S. (2010) Study of Photovoltaic and Inverter Characteristics. Universiti Malaysia Perlis (UniMAP), Malaysia.

[23] Shaari, S., Omar, A.M., Haris, A.H., Sulaiman, S.I. and Muhammad, K.S. (2009) Solar Photovoltaic Power: Design and Installation of Stand-Alone Systems. Pusat Tenaga Malaysia, 46-52, 119-129.

[24] Benghanem, M. (2011) Optimization of Tilt Angle for Solar Panel: Case Study for Madinah, Saudi Arabia. Applied Energy, 88, 1427-1433.

[25] Cengel, Y.A. and Boles, M.A. (2015) Thermodynamics: An Engineering Approach. 8th Edition, McGraw Hill, New York.

[26] http://www.engineeringtoolbox.com/r22-properties-d_365.html 